\title{
TPACK SEBAGAI SOLUSI GURU SEKOLAH DASAR UNTUK MENINGKATKAN HASIL BELAJAR TEMATIK SISWA DI ERA PANDEMI COVID'19
}

\author{
Nurhanifa Tamba \\ Universitas Negeri Medan, Indonesia. \\ Email: nifatamba26@gmail.com
}

\begin{abstract}
COVID-19 is a disease outbreak that originated in China and spread rapidly throughout the world. COVID-19 spread in Indonesia in early March 2020. The spread of this virus caused losses to many countries, especially in the field of education, therefore TPACK is a solution for elementary school teachers to improve student thematic learning outcomes in the era of the covid'19 pandemic which is carried out online. . TPACK is a theoretical framework for integrating technology, pedagogy, and materials such as interactive powerpoints. Researchers collected data through interview observations, surveys and blended learning methods. This research is the third grade students of SD Negeri 157013 Sibabangun 5 Tapanuli Middle of the Academic Year 2021/2022. Sampling was done by purposive sampling technique. That is by taking two classes taught by the same teacher. The initial conditions were obtained from daily test 1 with an average value of 51.05 as the control class, namely conventional learning. While the average value is 91.32 as the experimental class, namely TPACKbased learning using interactive powerpoint. By mastering TPACK, elementary school teachers can present TPACK-based learning for example powerpoint, Lectora inspire, short videos and so on related to the material to be studied and become the best solution when learning is done online and in accordance with the industrial revolution 4.032 as an experimental class, namely TPACK-based learning using interactive powerpoints. By mastering TPACK, elementary school teachers can present TPACK-based learning for example powerpoint, Lectora inspire, short videos and so on related to the material to be studied and become the best solution when learning is done online and in accordance with the industrial revolution 4.032 as an experimental class, namely TPACK-based learning using interactive powerpoints. By mastering TPACK, elementary school teachers can present TPACK-based learning for example powerpoint, Lectora inspire, short videos and so on related to the material to be studied and become the best solution when learning is done online and in accordance with the industrial revolution 4.0
\end{abstract}

Keywords: Covid-19, TPACK, Online learning

\begin{abstract}
ABSTRAK
COVID-19 merupakan wabah penyakit yang berasal dari Tiongkok yang menyebar dengan cepat ke seluruh dunia. COVID-19 menyebar di Indonesia pada awal Maret 2020. Penyebaran virus ini menyebabkan kerugian untuk banyak negara terutama dalam bidang bidang pendidikan, oleh karena itu TPACK sebagai solusi guru sekolah dasar untuk meningkatkan hasil belajar tematik siswa di era pandemi covid'19 yang dilakukan secara daring. TPACK merupakan kerangka teoritis untuk mengintegrasikan teknologi, pedagogik, dan materi seperti powerpoint interaktif. Peneliti mengumpulkan data melalui observasi wawancara, survei dan metode blended learning. Penelitian ini adalah siswa kelas III SD Negeri 157013 Sibabangun 5 Tapanuli Tengah Tahun Ajaran 2021/2022. Pengambilan sampel dilakukan dengan teknik purposive sampling. Yaitu dengan mengambil dua kelas yang diajarkan dengan guru yang sama. Kondisi awal diperoleh dari ulangan harian 1 dengan nilai ratarata 51,05 sebagai kelas kontrol yaitu pembelajaran konvensional. Sedangkan nilai rata-rata 91,32 sebagai kelas eksperimen yaitu pembelajaran berbasis TPACK dengan menggunakan powepoint interaktif. Dengan menguasai TPACK guru sekolah dasar dapat menyajikan pembelajaran yang berbasis TPACK contohnya powerpoint, lectora inspire, video singkat dan lain sebagainya yang berkaitan dengan materi yang akan dipelajari dan menjadi solusi terbaik ketika pembelajaran dilakukan secara daring serta sesuai dengan revolusi industri 4.0
\end{abstract}

Kata Kunci: Covid-19,TPACK, Pembelajaran Online 


\section{PENDAHULUAN}

Latar belakang virus Corona atau COVID-19, kasusnya dimulai dengan pneumonia atau radang paru-paru misterius pada Desember 2019. Kasus ini diduga berkaitan dengan pasar hewan Huanan di Wuhan yang menjual berbagai jenis daging binatang, termasuk yang tidak biasa dikonsumsi, misal ular, kelelawar, dan berbagai jenis tikus. Covid 19 merupakan penyakit yang sangat mudah terjadinya penyebaran, dimana virus ini secara khusus menyerang sistem pernafasan manusia (Rothan dan Byrareddy, 2020).

Pada tanggal 24 maret 2020 Menteri Pendidikan dan Kebudayaan Republik Indonesia mengeluarkan Surat Edaran Nomor 4 Tahun 2020 Tentang Pelaksanaan Kebijakan Pendidikan Dalam Masa Darurat Penyebaran COVID, dalam Surat Edaran tersebut dijelaskan bahwa proses belajar dilaksanakan di rumah melalui pembelajaran online untuk memberikan pengalaman belajar yang bermakna bagi siswa. Pembelajaran yang dilaksanakan melalui belajar dari rumah dapat dilaksanakan dengan bimbingan serta bantuan orangtua, dengan begitu siswa bisa belajar kapanpun dan dimanapun, guru hanya memberikan soal, materi serta ulangan harian melalui pembelajaran online yang digunakan seperti: Classroom, Whatsapp, Zoom.

Untuk memudahkan guru dengan siswa belajar dari rumah. sebaliknya siswa akan memahami materi yang diberikan oleh guru serta mengirim tugas yang diberikan oleh guru dari aplikasi yang dipakai oleh guru dan siswa tanpa tatap muka (Hartanto, 2016). Pembelajaran online diartikan sebagai suatu jaringan komputer yang saling terkoneksi dengan jaringan komputer lainnya ke seluruh penjuru dunia. namun pembelajaran yang dilakukan secara daring ini merupakan satu-satunya solusi untuk menekan penyebaran covid 19.

Dalam pembelajaran daring, siswa merasa lebih nyaman untuk bertanya dan mengemukakan pendapat dalam forum yang dilaksanakan secara online (Firman \& Sari, 2020:84). Kuo et al (2014) menyatakan bahwa pembelajaran online lebih mengarah pada student centered sehingga mampu memunculkan tanggung jawab dan siswa lebih mampu menumbuhkan kemandirian dalam belajar.

Sementara itu kemampuan dan kesiapan guru mengintegrasikan teknologi dalam pembelajaran merupakan bentuk professionalitas guru. Sebagai profesi tentu guru harus mempunyai kemampuan mengelola pembelajaran dan memanfaatkan kemajuan teknologi di era industri 4.0 secara kreatif dan inovatif agar pembelajaran berjalan sesuai harapan dan tujuan (Wahyono, 2020) Dengan kemampuan mengintegrasikan teknologi didalam pembelajaran merupakan suatu hal yang menarik yang membentuk pembaharuan dan harus dikembangkan oleh seorang guru.

Secara garis besar didalam TPACK mengambarkan tentang tiga komponen utama yaitu: pedagogik, konten, teknologi, yang dapat dijadikan sebagai dasar dalam mengembangkan diri dan inovasi pembelajaran (Surryawati dkk, 2014:68). Untuk membuat kegiatan pembelajaran meningkat guru harus mempunyai pengetahuan agar pengintegrasian teknologi dalam pembelajaran dapat dilakukan guru secara optimal. Pengetahuan tersebut disebut dengan TPACK (Technological Pedagogical Content Knowledge).

Keuntungan penggunaan pembelajaran TPACK adalah pembelajaran bersifat mandiri dan interaktivitas yang tinggi, mampu meningkatkan tingkat ingatan, memberikan lebih banyak pengalaman belajar, dengan teks, audio, video dan animasi yang semuanya digunakan untuk menyampaikan informasi, mengunduh, para siswa juga bisa mengirim email kepada siswa lain, mengirim komentar pada forum diskusi, memakai ruang chat, (Arnesti \& Hamid, 2015). 
Secara garis besar didalam TPACK mengambarkan tentang tiga komponen utama yaitu: pedagogik, konten, teknologi, yang dapat dijadikan sebagai dasar dalam mengembangkan diri dan inovasi pembelajaran (Suryyawati dkk, 2014:68). Tetapi faktanya di dalam ruang lingkup pendidikan masih banyak guru sekolah dasar yang masih belum bisa mengintegrasikan teknologi ke dalam pembelajaran. Masih banyak pembelajaran yang ditemui di lapangan masih berpusat pada guru bukan berpusat pada siswa. Sehingga siswa kurang mendapatkan kesempatannya dalam mengembangkan pengetahuannya.

Terkhusus pembelajaran tematik dimana selama pembelajaran daring guru hanya memberikan tugas atau latihan saja tanpa ada pembahasan materi pembelajaran sedikitpun. Sehingga semakin membuat siswa tidak merespon dengan baik materi pembelajaran yang diberikan tersebut. Hingga berujung pada hasil pembelajaran yang menurun. Oleh karena itu artikel ini membahas TPACK sebagai solusi guru sekolah dasar untuk meningkatkan hasil belajar tematik siswa di era pandemi covid'19.

\section{METODE PENELITIAN}

Metode penelitian menurut Sugiyono (2015) diartikan sebagai cara ilmiah untuk mendapatkan data dengan tujuan dan kegunaan tertentu. Kajian ini menggunakan pendekatan kuantitatif. Penelitian mengumpulkan data melalui observasi wawancara, metode survei dan metode blended learning. Metode blended yaitu daring dan luring yang digunakan untuk mendapatkan data dari tempat tertentu yang alamiah (bukan buatan), tetapi peneliti melakukan perlakuan dalam pengumpulan data, misalnya dengan mengedarkan kuesioner, tes, dan wawancara yang terstruktur. Populasi penelitian ini adalah siswa kelas III SD Negeri 157013 semester genap tahun ajaran 2021/2022. Pengambilan sampel dilakukan dengan teknik purposive sampling, yaitu dengan mengambil dua kelas yang diajarkan dengan guru yang sama. Kondisi awal siswa yang relatif sama diperoleh dari nilai rata-rata ulangan harian 1 . Terpilih kelas III-B dangan nilai rata-rata 51,05 sebagai kelas kontrol yaitu kelas dengan pembelajaran konvensional dan kelas III-A dengan nilai rata-rata kemampuan awal 91,32 sebagai kelas eksperimen dengan pembelajaran berbasis TPACK menggunakan powerpoint interaktif

\section{HASIL DAN PEMBAHASAN}

Hasil penelitian menunjukkan bahwa pembelajaran yang dilaksanakan di SD Negeri 157013 semenjak adanya virus COVID-19 yaitu menggunakan sistem pembelajaran online. Namun pembelajaran daring juga memiliki tantangan tersendiri. Salah satunya adalah ketersediaan jaringan internet. Beberapa mengaku kesulitan untuk mengikuti pembelajaran online karena tidak semua wilayah mendapatkan jaringan internet dengan akses lancar (Hasanah dkk, 2020).

Pembelajaran daring pada saat ini menjadi hal yang paling populer karena adanya covid'19, oleh karena itu banyak sekarang yang menawarkan berbagai aplikasi untuk melakukan pembelajaran daring. Tergantung gurunya yang mengelola dan menimalisir pembelajaran sebaik mungkin dan semenarik mungkin. TPACK merupakan kerangka teoritis untuk mengintegrasikan teknologi, pedagogik, dan materi seperti powerpoint, lectora inspire, video singkat dan lain sebagainya yang berkaitan dengan materi yang akan dipelajari

TPACK (Technological Pedagogical Content Knowledge) merupakan sebuah kerangka kerja yang diperkenalkan oleh Punya Mishra dan Matthew J. Koehler. Kerangka ini merupakan pengembangan dari model Shulman (1986) terkait 
pengetahuan konten dan pedagogi atau yang dikenal dengan PCK (Pedagogical Content Knowledge). Dalam hal ini, Mishra dan Koehler menambahkan teknologi ke dalam konsep PCK sehingga menjadi TPACK. TPACK dikenal sebagai kerangka teori untuk memahami pengetahuan guru dalam penggunaan teknologi dalam pembelajaran secara efektif. Pengetahuan terkait teknologi, pedagogik, dan pengetahuan konten merupakan kompetensi dasar yang harus dimiliki oleh guru di abad 21.

Kemampuan guru untuk mengetahui dan menguasai teknologi, pedagogi dan konten (TPACK) menjadi tanggung jawabnya sebagai penyampai pesan (sender) kepada siswa sebagai penerima pesan (receiver) (Ibnu, 2019). Menurut (Matthew, 2014) Ada tiga komponen pengetahuan utama yang membentuk dasar TPACK, antara lain: a) Content Knowledge (CK) atau pengetahuan konten. Pengetahuan ini mengacu pada berbagai mata pelajaran yang menjadi tanggung jawab seorang guru. Pengetahuan ini mencakup pengetahuan tentang konsep, teori, ide, serta praktik dan pendekatan dalam mengembangkan pengetahuan tersebut. b) Pedagogical Knowledge (PK) atau pengetahuan pedagogis. Pengetahuan guru terkait beragam strategi pembelajaran, metode pembelajaran, serta praktik pembelajaran. c) Technology Knowledge (TK) atau pengetahuan teknologi. Pengetahuan guru terkait teknologi, baik teknologi tradisional maupun modern yang dapat diintegrasikan dalam proses pembelajaran.

Hasil penelitian menilai pembelajaran TPACK dengan menggunakan powerpoint interaktif secara efektif (92\%), sebagian mereka menilai tidak efektif $(8 \%)$ dan pembelajaran daring yang tidak menggunakan TPACK hanya sistem konvensional secara efektif (15\%), sebagian mereka menilai tidak efektif (85\%).

\section{PENUTUP}

Pada saat pandemi covid-19 pembelajaran daring dimulai dengan metode belajar online dirumah. Pada saat pandemi covid'19 membuat sebuah peluang dalam dunia pendidikan baik pemanfaatan teknologi seiring denagn industri 4.0, maupun orangtua sebagai mentor. Walau tugas pembelajaran daring yang diberikan kepada peserta didik selayaknya menuju kecakapan abad 21 tersebut. Namun ada juga disisi negatifnya karena pembelajaran online tidak mudah dilakukan. Karena banyaknya hambatan yang ada seperti koneksi internet tidak stabil, anak juga keseringan main handphone serta anak kurang bergaul dengan teman-temannya hanya berfokus pada handphone saja. Walaupun begitu guru harus terus menerus menggunakan pembelajaran daring karena adanya covid'19 dan guru harus dituntut untuk menguasai teknologi TPACK. TPACK dikenal sebagai kerangka teori untuk memahami pengetahuan guru dalam penggunaan teknologi dalam pembelajaran secara efektif. Pengetahuan terkait teknologi, pedagogik, dan pengetahuan konten merupakan kompetensi dasar yang harus dimiliki oleh guru di abad 21. Salah satunya dengan menggunakan media pembelajaran TPACK dalam pembelajaran PKn sehingga siswa merasa tertarik dan mendapatkan hasil yang memuaskan di dalam pembelajaran tematik tersebut.

\section{DAFTAR PUSTAKA}

Arnesti, N., \& Hamid, A. (2015). Penggunaan Media Pembelajaran Online - Offline Dan KomunikasiInterpersonal Terhadap Hasil Belajar Bahasa Inggris. Jurnal Teknologi Informasi \& Komunikasi Dalam Pendidikan, 2 (1). https://doi.org/10.24114/ jtikp.v2i1.3284.

Firman \& Sari. (2020). Pembelajaran Online di Tengah Pandemi Covid-19. Indonesian Journal Of Educational Science (IJES), Volume 02 No 02.

Hartanto, W. (2016). Penggunaan E-Learning sebagai Media Pembelajaran. Jurnal 
Pendidikan Ekonomi, 10(1), 1-18.

Hasanah, dkk. 2020. Analisis Aktivitas Belajar Daring Mahasiswa Pada Pandemi COVID-19. Jurnal Pendidikan. Volume 1 No.1.

Ibnu Rofi, "Nurrita Sabrina, Pengintegrasian TPACK Dalam Pembelajaran Transformasi Geometri SMA untuk Mengembangkan Profesionatas Guru Matematika," SJME (Supremum Journal of Mathematics Education) 3, No.1, (2019) https://osf.io/preprints/socarxiv/v2ygb/.

Kuo, et al. (2014). Interaction, Internet self-efficacy, and self-regulated learning as predictors of student satisfaction in online education courses. Volume 20, pages $35-50$.

Matthew J. Koehler et al., "The Technological Pedagogical Content Knowledge Framework," Handbook of Research on Educational Communications and Technology: Fourth Edition

(2014)

https://asu.pure.elsevier.com/en/publications/the-technological-pedagogicalcontent-knowledge-framework

Matthew J. Koehler et al., "The Technological Pedagogical Content Knowledge Framework," Handbook of Research on Educational Communications and Technology: Fourth Edition, January 1, 2014, 101-11, https://doi.org/10.1007/978-1-4614-3185-5_9., 103.

Poncojari Wahyono, cs., "Guru Profesional Di Masa Pandemi COVID-19: Review Implementasi, Tantangan, Dan Solusi Pembelajaran Daring”, Jurnal Pendidikan Profesi Guru (JPPG) Universitas Muhammadiyah Malang 1, No.1(2020)http://ejournal.umm.ac.id/index.php/jppg/article/view/12462

Sugiyono. (2012). Metode Penelitian Kuantitatif Kualitatif dan R\&D. Alfabeta.

Suryyawati, Evi., Hernandez, Yosua. 2014. Analisis ketrampilan Technological Pedagogical Content Knowledge (TPCK) Guru Biologi SMA Negeri Kota Pekanbaru. Jurnal Biogenesis. Vol. 11. Pekanbaru. Dapat di akses melalui https://ejournal.unri.ac.id/index.php/JPSB/article/view/2478

Rothan, H. A., \& Byrareddy, S. N. (2020). The Epidemiology and Pathogenesis of Coronavirus Disease (Covid-19) 